\title{
"Smoking paradox" is not true in patients with ischemic stroke: a systematic review and meta-analysis
}

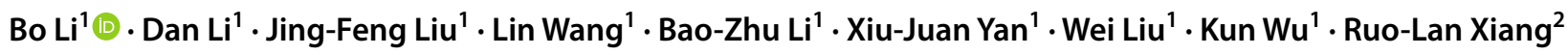

Received: 9 September 2019 / Revised: 17 October 2019 / Accepted: 18 October 2019 / Published online: 29 October 2019

(c) The Author(s) 2019

\begin{abstract}
Background Ischemic stroke (IS) is a common cause of death from vascular diseases. Studies have found that smoking increases the risk of ischemic stroke, but the association of smoking with the outcome of IS remains unclear. This metaanalysis aims to investigate the effect of smoking on the prognosis of IS.

Methods We searched four electronic databases including PubMed, EMBASE, Cochrane library and Web of science for papers, published before January 2019. In this meta-analysis, Review Manager 5.3 software was used to calculate for the pooled estimate effect, as well as the inverse-variance method for pooled mean difference (MD) and odds ratio (OR) of incidence in two groups of population.

Results A total of 14,789 citations were identified during the literature search, 21 studies were included in the meta-analyses after screening. The full-adjusted OR of poor prognostic outcome in smoking and nonsmoking patients with stroke was pooled as 0.96 (95\% CI 0.77-1.21), suggested that smoking or not has no impact on prognosis of IS. The pooled MD of onset age between smoking and nonsmoking IS patients was $-10.05(-12.91,-7.19)$, indicated that smoking causes first onset of IS to occur 10 years earlier.

Conclusions This meta-analysis showed that smoking was not a protective factor for poor prognosis of IS. Smoking patients with IS are 10 years younger than nonsmoking patients at time of the first onset of stroke.
\end{abstract}

Keywords Ischemic stroke $\cdot$ Smoking $\cdot$ Poor outcome $\cdot$ Prognosis $\cdot$ Meta-analysis

$\begin{array}{ll}\text { Abbreviations } \\ \text { ES } & \text { Effect size } \\ \text { IS } & \text { Ischemic stroke } \\ \text { MD } & \text { Mean differences } \\ \text { NIHSS } & \text { National Institute of Health Stroke Scale } \\ \text { OR } & \text { Odds ratio } \\ \text { SS } & \text { Statistical significance }\end{array}$

Bo Li

13691089898@139.com

Ruo-Lan Xiang

xiangrl@bjmu.edu.cn

1 Department of Neurology, Beijing Hepingli Hospital, No.18 North Street Hepingli, Dongcheng District, Beijing 100013, China

2 Department of Physiology and Pathophysiology, Key Laboratory of Molecular Cardiovascular Sciences, Ministry of Education, and Beijing Key Laboratory of Cardiovascular Receptors Research, Peking University School of Basic Medical Sciences, No.38 Xueyuan Road, Haidian District, Beijing 100191, China

\section{Introduction}

Ischemic stroke (IS) is the second most common cause of death from vascular diseases and the third major cause of disability worldwide [1]. The previous studies showed that the overall incidence of first-time strokes increased by $11.9 \%$ annually (12.4\% for men and $9.0 \%$ for women) from 1992 to 2015 [2]. In 2015 alone, there were 42.4 million stroke patients nationwide, including 24.9 million IS patients and 3 million deaths from IS. It has been become particularly important to effectively reduce the incidence of IS.

Smoking causes a variety of diseases and kills nearly 6 million people every year (WHO, 2015). Although the prevalence of smoking has decreased in the past 30 years, the absolute number of smokers still increases due to the rapid growth of population, that is, from 721 million in 1980 to 967 million in 2012 [3]. Currently, active smoking is a recognized risk factor for stroke, with $12.4 \%$ of accidental stroke patients attributable to current smoking [4]. Studies have found that pre-stroke smoking has a negative or neutral effect on the prognosis of stroke [5-12]. But recent 
studies reported the so-called "smoker's paradox", suggesting that smokers who undergo thrombolytic therapy have better clinical outcomes. This paradox has been found in patients with myocardial infarction and IS treated with intravenous thrombolysis (IVT), and studies have shown that IS patients who experience smoking may have better recovery and better thrombolytic response than non-smokers. Nevertheless, some researchers insisted that the smoking paradox is caused by variances from case to case and that smoking is not an independent prognostic factor in patients with ischemic stroke. The influence of smoking on the prognosis of IS patients, including the influence of passive smoking on IS has not been clearly defined yet.

Based on these conflicting results, the aims of this metaanalysis were to explore the prognostic effects of smoking on IS patients.

\section{Methods}

The authors declare that all supporting data are available within the article (and its online supplementary files). This meta-analysis was performed according to the PRISMA guidelines [13]. We used publicly available published studies, and our study was exempt for approval from Institutional Review Board.

\section{Eligibility criteria}

Eligible trials had to satisfy the following prespecified PICOS criteria: (1) P: ischemic stroke patients; (2) I: smoking; (3) C: no smoking; (4) O: odds ratio of poor prognosis or severity of admission; and (5) S: prospective or retrospective study.

\section{Search strategy}

We conducted a systematic search for articles published before January 2019 without language and data restrictions, through PubMed (Medline), EMBASE (Excerpta Medica Database), Cochrane library and Web of Science computerized databases. The following search terms were used: "ischemic stroke" or "brain ischemia" or "cerebral infarction" or "cerebral vasospasm" or "cerebral angiospasm" or "cerebrovascular obstruction" and "cigarette" or "smoking". During the search process, we not only used MeSH keywords for retrieval, but also used a broader range of search terms to collect all articles related to this topic. We not only searched the original published articles, but also the references cited in the relevant review articles. In addition, we also retrieved relevant conferences abstracts, reviews and the publications of experts.

\section{Selection criteria}

All the literatures were proceeded to full-text screening by two reviewers. Their detailed examination of the full text would lead the studies to be included or excluded. If there were duplicate studies, the earlier or more detailed publications would be included. If the review contained original published data, it would be also included.

\section{Data extraction and analysis}

One investigator used a pre-designed sheet to extract and document data from eligible studies, including authors, publication year, study design, population, age, male, sample size, grouping and number of people in the group, data including counts and effect estimates, country, follow-up years, title, conclusion. Another investigator independently reviewed to ensure accuracy of data.

\section{Statistical methods}

Review Manager Software version 5.3. from the Cochrane Collaboration (London, United Kingdom) was used to calculate the pooled estimate effect and the inverse-variance method was used to combine effect size. The mean differences (MD) of NIHSS score between the smoking and nonsmoking groups of IS patients were pooled to explore the association of smoking or not with the severity of illness at time of admission to hospital. Meanwhile, the prognosis of IS patients who smoke or do not smoke was studied to produce odds ratio (OR) of poor functional outcome. The between-study heterogeneity was measured by $I^{2}$ statistic and $\mathrm{Q}$ test. $P<0.01$ was deemed as significant heterogeneity. We pooled effect size (ES) estimates with significant heterogeneity using random-effects model, otherwise using fixed-effects model.

\section{Quality assessment and risk of bias across studies}

We used the Newcastle-Ottawa Scale (NOS) for assessing the quality of the studies in meta-analyses. We visualized possible publication bias by means of a funnel plot, i.e., ES scatter plots, estimated from single study to compare with their standard deviation. 
Fig. 1 Flowchart of study selection

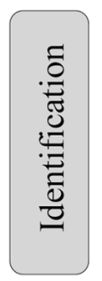

All records identified through database searching $(\mathrm{n}=14798)$

- PubMed $(n=1016)$

- EMBASE $(\mathrm{n}=5443)$

- Cochrane library $(n=580)$

- Web of science $(\mathrm{n}=7759)$
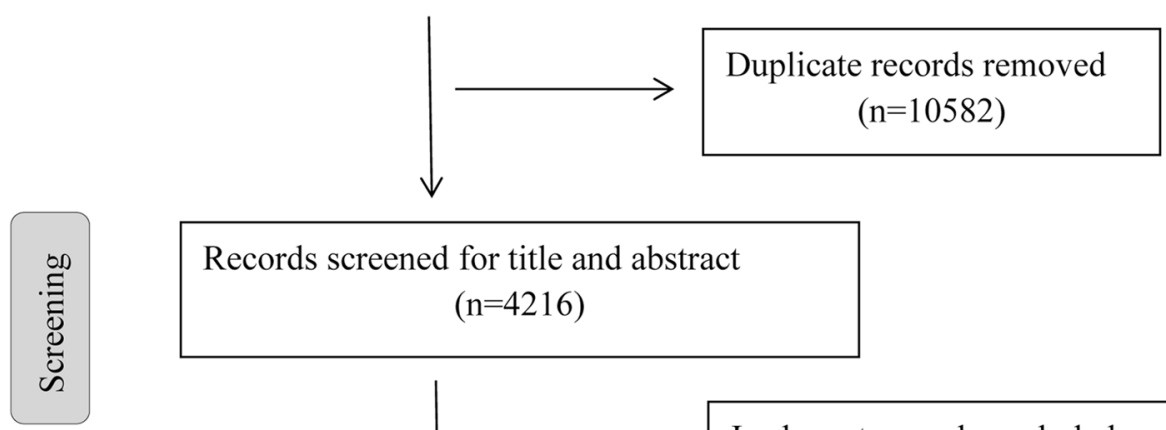

Records screened for title and abstract $(n=4216)$
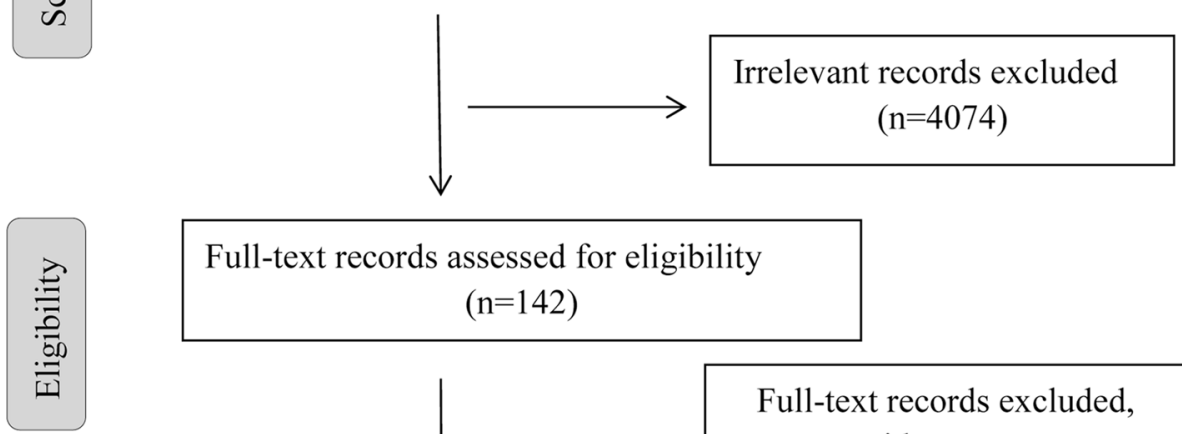

Full-text records assessed for eligibility $(n=142)$

Records included in meta-analysis $(\mathrm{n}=18)$

\section{Results}

\section{Eligible studies}

14,789 related electronic citations were tracked. The flowchart of the study selection is depicted in Fig. 1. As a result, 142 articles were included following title/abstract screening and 124 articles were excluded following fulltext artificial selection. Among them were: review article $(n=25)$, non-human $(n=8)$, case report $(n=4)$, human cell $(n=10)$, conference paper $(n=33)$, study design $(n=25)$, insufficient information for a meta-analysis $(n=16)$, others $(n=3)$. In the end, 18 articles were included in the meta-analysis.

\section{Description of studies}

In this meta-analysis, 18 articles with a total sample size of 987,074 were included. The detailed information of each 
Table 1 Characteristics of included studies

\begin{tabular}{|c|c|c|c|c|c|c|c|c|}
\hline Study & Years & Study design & Population & Age & Male (\%) & Sample size & Country & $\begin{array}{l}\text { Follow- } \\
\text { up (year) }\end{array}$ \\
\hline Ali [14] & 2013 & Prospective cohort study & $\begin{array}{l}\text { Using our hospital's Get } \\
\text { with the Guidelines- } \\
\text { Stroke (GWTGStroke) } \\
\text { registry, we analyzed } \\
\text { patients consecutively } \\
\text { admitted with AIS }\end{array}$ & $59.6 \pm 13.8$ & 60.0 & 4305 & USA & 0.0 \\
\hline Ali [15] & 2015 & $\begin{array}{l}\text { Retrospective cohort } \\
\text { study }\end{array}$ & $\begin{array}{l}\text { Using our hospital's Get } \\
\text { with the Guidelines- } \\
\text { Stroke (GWTGStroke) } \\
\text { registry, we analyzed } \\
\text { patients consecutively } \\
\text { admitted with AIS }\end{array}$ & $70.3 \pm 14.8$ & 48.5 & 899,295 & Canada & 0.0 \\
\hline Bejot [16] & 2014 & Prospective cohort study & $\begin{array}{l}\text { All patients diagnosed } \\
\text { with a first-ever IS } \\
\text { occurring between 1st } \\
\text { January } 2006 \text { and } 31 \text { st } \\
\text { December } 2011 \text { were } \\
\text { prospectively identified } \\
\text { among residents of the } \\
\text { city of Dijon, France } \\
\text { (2007 census: } 151,543 \\
\text { inhabitants) from the } \\
\text { Dijon Stroke Registry }\end{array}$ & $63.3 \pm 16.7$ & 65.2 & 973 & France & 0.0 \\
\hline Chung [17] & 2016 & $\begin{array}{l}\text { Retrospective cohort } \\
\text { study }\end{array}$ & $\begin{array}{l}\text { We retrieved data from } \\
\text { TVGHSR on patients } \\
\text { who were consecu- } \\
\text { tively admitted and } \\
\text { registered between } \\
\text { January } 1,2012 \text { and } \\
\text { February } 28,2014\end{array}$ & $74.9 \pm 8.9$ & 75.0 & 60 & Taiwan & 1.0 \\
\hline Edjoc [9] & 2013 & Prospective cohort study & $\begin{array}{l}\text { The Registry of the } \\
\text { Canadian Stroke Net- } \\
\text { work (RCSN) contains } \\
\text { data for over 50,000 } \\
\text { strokes in Canada. } \\
17 \text { participating sites } \\
\text { include all Ontario } \\
\text { acute care institutions. } \\
\text { A cohort of } 20,523 \\
\text { patients was selected } \\
\text { for this study from the } \\
\text { RCSN }\end{array}$ & $61.8 \pm 13.17$ & 52.1 & 20,523 & Canada & 1.0 \\
\hline Fekete [10] & 2014 & $\begin{array}{l}\text { Retrospective cohort } \\
\text { study }\end{array}$ & $\begin{array}{l}\text { The database of the } \\
\text { Mures Uzhgorod } \\
\text { Debrecen study was } \\
\text { analyzed. Altogether } \\
1049 \text { patients are } \\
\text { recorded in the data- } \\
\text { base ( } 603 \text { men) }\end{array}$ & - & - & 716 & Hungary & 1.0 \\
\hline Glymour [18] & 2008 & Prospective cohort study & $\begin{array}{l}\text { The Health and Retire- } \\
\text { ment Study (HRS) is a } \\
\text { national, longitudinal } \\
\text { survey of U.S. adults } \\
\text { aged } \geq 50 \text { years and } \\
\text { their spouses. } 10-12 \\
\text { Enrollments occurred } \\
\text { in } 1992,1993,1998, \\
\text { and } 2004, \text { staggered by } \\
\text { birth cohort }\end{array}$ & 61 & - & 16,225 & USA & 9.1 \\
\hline
\end{tabular}


Table 1 (continued)

\begin{tabular}{|c|c|c|c|c|c|c|c|c|}
\hline Study & Years & Study design & Population & Age & Male (\%) & Sample size & Country & $\begin{array}{l}\text { Follow- } \\
\text { up (year) }\end{array}$ \\
\hline Hou [19] & 2017 & Case-control study & $\begin{array}{l}\text { A dataset from the China } \\
\text { Nationwide Retrospec- } \\
\text { tive Mortality Survey, } \\
\text { conducted from } 1989 \\
\text { through 1991, was } \\
\text { used. This survey } \\
\text { included 1,136,686 } \\
\text { all-cause deaths of } \\
\text { subjects aged } 30 \text { years } \\
\text { or older during the } \\
\text { years } 1986-1988 \\
\text { from } 24 \text { urban areas } \\
\text { and } 79 \text { rural counties } \\
\text { randomly chosen from } \\
\text { over } 2000 \text { counties in } \\
\text { China }\end{array}$ & $64.9 \pm 10.4$ & 66.7 & 32,410 & China & 0.0 \\
\hline Hou [20] & $2017 \mathrm{a}$ & Prospective cohort study & $\begin{array}{l}\text { First-ever ischemic } \\
\text { stroke patients hospi- } \\
\text { talized in the Depart- } \\
\text { ment of Neurology, } \\
\text { West China Hospital, } \\
\text { Sichuan University } \\
\text { were eligible for this } \\
\text { study. A total of } 720 \\
\text { first-ever ischemic } \\
\text { stroke patients were } \\
\text { recruited during } \\
\text { 2010-2014 }\end{array}$ & $61.5 \pm 12.4$ & 100.0 & 378 & China & 3.0 \\
\hline $\operatorname{Kim}[5]$ & 2012 & Prospective cohort study & $\begin{array}{l}1589 \text { cases of first-ever } \\
\text { and recurrent stroke } \\
\text { were recruited between } \\
1996 \text { and } 1999 \text { from a } \\
\text { defined geographical } \\
\text { region in North East } \\
\text { Melbourne. Both hos- } \\
\text { pital and nonhospital } \\
\text { cases were included }\end{array}$ & - & 48.3 & 1230 & Australia & 10.0 \\
\hline Kumagai [6] & 2013 & Prospective cohort study & $\begin{array}{l}\text { Patients were enrolled in } \\
\text { this study from partici- } \\
\text { pants in the Edaravone } \\
\text { and Argatroban Stroke } \\
\text { Therapy (EAST) for } \\
\text { Acute Ischemic Stroke } \\
\text { study. The study began } \\
\text { in August } 2004 \text { and } \\
\text { ended in May } 2008\end{array}$ & $71.9 \pm 9.7$ & 59.8 & 660 & Japan & 0.2 \\
\hline
\end{tabular}


Table 1 (continued)

\begin{tabular}{|c|c|c|c|c|c|c|c|c|}
\hline Study & Years & Study design & Population & Age & Male $(\%)$ & Sample size & Country & $\begin{array}{l}\text { Follow- } \\
\text { up (year) }\end{array}$ \\
\hline Lee $[21]$ & 2015 & $\begin{array}{l}\text { Retrospective cohort } \\
\text { study }\end{array}$ & $\begin{array}{l}\text { Subjects were consecu- } \\
\text { tive patients with first- } \\
\text { ever ischemic stroke } \\
\text { and without previous } \\
\text { functional disability } \\
\text { (modified Rankin Scale } \\
\text { [mRS] score > 1) who } \\
\text { were admitted to Hal- } \\
\text { lym University Medical } \\
\text { Center within } 7 \text { days } \\
\text { of symptom onset } \\
\text { between October } 2007 \\
\text { and July 2012. The } \\
\text { data were populated } \\
\text { from the Hallym Stroke } \\
\text { Registry, a prospective } \\
\text { hospital-based stroke } \\
\text { database }\end{array}$ & $65.3 \pm 13.5$ & 57.4 & 1113 & Korea & 0.2 \\
\hline Ovbiagele [22] & 2005 & Prospective cohort study & $\begin{array}{l}\text { Data from Trials } 1 \text { and } \\
2 \text { of the National } \\
\text { Institute of Neuro- } \\
\text { logical Disorders and } \\
\text { Stroke (NINDS) Tissue } \\
\text { Plasminogen Activa- } \\
\text { tor (tPA) Study were } \\
\text { analyzed }\end{array}$ & 64.19 & 57.0 & 305 & USA & 1.0 \\
\hline Ovbiagele [7] & 2006 & Prospective cohort study & $\begin{array}{l}\text { We abstracted data from } \\
\text { the IMAGES trial data- } \\
\text { base for this analysis. } \\
\text { We identified } 2386 \\
\text { subjects with acute } \\
\text { ischemic stroke }\end{array}$ & - & 53.5 & 2386 & USA & 0.2 \\
\hline Tong [23] & 2016 & Prospective cohort study & $\begin{array}{l}\text { TIMS-China was a } \\
\text { national prospective } \\
\text { stroke registry of } \\
\text { thrombolytic therapy } \\
\text { with intravenous } \\
\text { alteplase for AIS } \\
\text { patients in } 67 \text { major } \\
\text { stroke centers in China. } \\
\text { Between May } 2007 \text { and } \\
\text { April 2012, 1440 AIS } \\
\text { patients treated with } \\
\text { IVT were registered } \\
\text { in the TIMS-China } \\
\text { project }\end{array}$ & - & 60.8 & 1118 & China & 0.2 \\
\hline
\end{tabular}


Table 1 (continued)

\begin{tabular}{|c|c|c|c|c|c|c|c|c|}
\hline Study & Years & Study design & Population & Age & Male (\%) & Sample size & Country & $\begin{array}{l}\text { Follow- } \\
\text { up (year) }\end{array}$ \\
\hline von Martial [24] & 2018 & Prospective cohort study & $\begin{array}{l}\text { This study was based } \\
\text { on the Bernese stroke } \\
\text { center database, a } \\
\text { systematic prospective } \\
\text { registry of consecutive } \\
\text { patients with ischemic } \\
\text { stroke treated at the } \\
\text { Stroke Center of } \\
\text { University Hospital of } \\
\text { Berne, Switzerland. } \\
\text { we analyzed all stroke } \\
\text { patients who under- } \\
\text { went EVT between } \\
\text { January } 2005 \text { and } \\
\text { December } 2015 . \text { A } \\
\text { total of } 935 \text { patients } \\
\text { were eligible for this } \\
\text { study }\end{array}$ & $68 \pm 13.9$ & 54.3 & 935 & Switzerland & 0.2 \\
\hline Weng [12] & 2011 & $\begin{array}{l}\text { Retrospective cohort } \\
\text { study }\end{array}$ & $\begin{array}{l}\text { Patient data were col- } \\
\text { lected from SRICHS. } \\
\text { There were a total of } \\
3843 \text { ischemic stroke } \\
\text { patients in the SRICHS } \\
\text { in } 2009 \text {. We included } \\
2740 \text { patients }\end{array}$ & $63.9 \pm 12.5$ & 62.7 & 2650 & Taiwan & 0.0 \\
\hline Zhang [25] & 2017 & $\begin{array}{l}\text { Retrospective cohort } \\
\text { study }\end{array}$ & $\begin{array}{l}\text { We retrospectively } \\
\text { reviewed the pro- } \\
\text { spectively maintained } \\
\text { stroke registry of a } \\
\text { single medical center } \\
\text { (Xuanwu Hospital) } \\
\text { comprising } 1910 \text { non- } \\
\text { cardiogenic ischemic } \\
\text { stroke patients con- } \\
\text { secutively discharged } \\
\text { from January } 2013 \text { to } \\
\text { October } 2014\end{array}$ & $58.68 \pm 11.60$ & 95.4 & 1792 & China & 1.0 \\
\hline Total 18 studies & & & & 987,074 & & & & \\
\hline
\end{tabular}

study is listed in Table 1 and the results of evaluating studies quality using NOS scale are listed in Table 2.

\section{Meta-synthesis of results}

We conducted meta-analysis of 11 studies, and produced a pooled OR (full adjusted) of poor prognostic outcome in smoking and nonsmoking groups of IS patients (OR $=0.96$, 95\% CI $0.77-1.21, P=0.74$ with no statistical significance (SS)). The common adjusted factors included age, sex, BMI and stroke severity at admission. The pooled OR suggested that smoking or not has no impact on prognosis of IS, and smoking is not a protective factor of poor prognostic outcome of IS. $I^{2}=86 \%$ was deemed as large heterogeneity (Fig. 2a). We carried out a subgroup meta-analyses and pooled OR of 90-day mortality in smoking group with ischemic stroke $(\mathrm{OR}=0.74,95 \%$ CI $0.47-1.15, P=0.18$ with no SS). $I^{2}=76 \%$ was deemed as moderately decreased heterogeneity. This overall effect size suggests that smoking or not was not related to the 90-day mortality of IS patients (Fig. 2b). In addition, we also pooled OR of unadjusted prognosis $(\mathrm{OR}=0.91,95 \% \mathrm{CI} 0.74-1.12, P=0.38$ heterogeneity $I^{2}=85 \%$ with no SS). Univariate analysis suggested that even if the covariates such as age, gender, BMI and stroke severity were not adjusted, smoking is not a protective factor for poor prognosis of IS (Fig. 2c). As three of above pooled effect sizes indicated, the smoking paradox is not supported by the fact that smoking or not is not related to poor prognostic outcome of IS.

We also studied the state of illness in smoking or nonsmoking groups at the time of admission and combined the $\mathrm{MD}$ of NIHSS score between the two groups $(\mathrm{MD}=-0.94$, 
Table 2 The NOS for assessing the quality of studies

\begin{tabular}{|c|c|c|c|}
\hline \multicolumn{4}{|l|}{ Cohort studies } \\
\hline Reference & Selection & Comparability & Outcome \\
\hline Ali 2013 [14] & 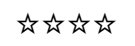 & 论弥 & is \\
\hline Ali 2015 [15] & 论论谈 & 计弥 & it \\
\hline Bejot 2014 [16] & 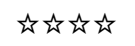 & 论弥 & is \\
\hline Chung 2016 [17] & 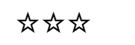 & 论弥 & 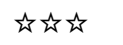 \\
\hline Edjoc 2013 [9] & 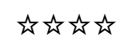 & 论弥 & 论败柁 \\
\hline Fekete 2014 [10] & 论许许 & 论访 & 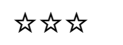 \\
\hline Glymour 2008 [18] & 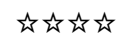 & 论弥 & 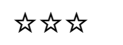 \\
\hline Hou 2017a [20] & 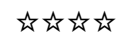 & 访访 & 论弥 \\
\hline Kim 2012 [5] & 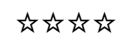 & 访㶦 & 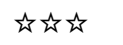 \\
\hline Kumagai 2013 [6] & 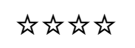 & 计场 & 访弥 \\
\hline Lee 2015 [21] & 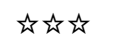 & 论㑔 & 论败弥 \\
\hline Ovbiagele 2005 [22] & 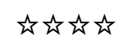 & 论弥 & 论败论 \\
\hline Ovbiagele 2006 [7] & 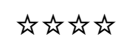 & 论弥 & 论弥 \\
\hline Tong2016 [23] & 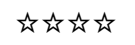 & 论弥 & 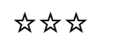 \\
\hline von Martial 2018 [24] & 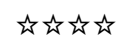 & 论弥 & 论败弥 \\
\hline Weng 2011 [12] & 论许许 & 论弥 & is \\
\hline Zhang 2017 [25] & 论许弥 & 访放 & 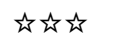 \\
\hline \multicolumn{4}{|l|}{ Case-control studies } \\
\hline Reference & Selection & Comparability & Exposure \\
\hline Hou 2017 [19] & 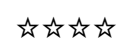 & 论岤 & 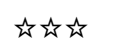 \\
\hline
\end{tabular}

$95 \% \mathrm{CI}-1.27$ to -0.60$)$. It showed the NIHSS score of "smoking group" was smaller than that of the "nonsmoking group" with a standard mean difference of -0.94 , which was statistically significant $(P<0.001)$. Heterogeneity $\left(I^{2}=84 \%\right)$ was large (Fig. 3). Although the effect size of the vast majority of included studies and the pooled overall effect size supported the notion that patients with cigarette smoking were less severe than patients without cigarette smoking at the time of admission, we believed this does not mean smoking is beneficial to the condition of ischemic stroke, as the NIHSS score is associated with a variety of other factors. We made comparison of onset age between smoking and nonsmoking IS patients (except Fekete 2014 for the absence of age data). The pooled MD was $-10.05(-12.91,-7.19)$, indicated that smoking brings forward the age of first onset of IS by 10 years. You can see from Fig. 4 .

\section{Publication bias and study quality}

The evaluation of quality was carried out for all 18 included studies and the results of NOS scale are shown in Table 2. To explore publication bias, we drew the funnel plot for the effect size of all the studies in Fig. 2a. The funnel plot visually was relatively symmetrical, as shown in Fig. 5a. The pooled effect size of the rest 10 studies varied from 0.96 to 0.95 , with no SS, and there is not any change in statistic $I^{2}$, even after that the study "Chung2016" was excluded due to deviation of its effect size too far. Therefore, we believed Chung2016 was insensitive to this comparison.

We also drew the funnel plot for the effect size of all the studies in Fig. 2c. The funnel plot visually was relatively symmetrical with little bias, as shown in Fig. 5 b.

As regards to publication bias of other comparisons, the funnel plot was of limited use due to the small number of studies evaluated.

\section{Discussion}

Eighteen studies comprising 987,074 patients were included in this meta-analysis. The results indicate that smoking is not a protective factor for poor prognosis in patients with IS, and the "smoking paradox" is not true. At the same time, it is found that smoking IS patients are 10 years younger than those who do not smoke, which further proves that smoking is an important risk factor for IS. Many studies are actively exploring the relationship between smoking and IS, and this possible link will have important implications for clinical practice and public health.

Smoking has long been considered as an independent risk factor for IS. Many studies reported smoking is an independent risk factor for poor prognosis in patients with ischemic 


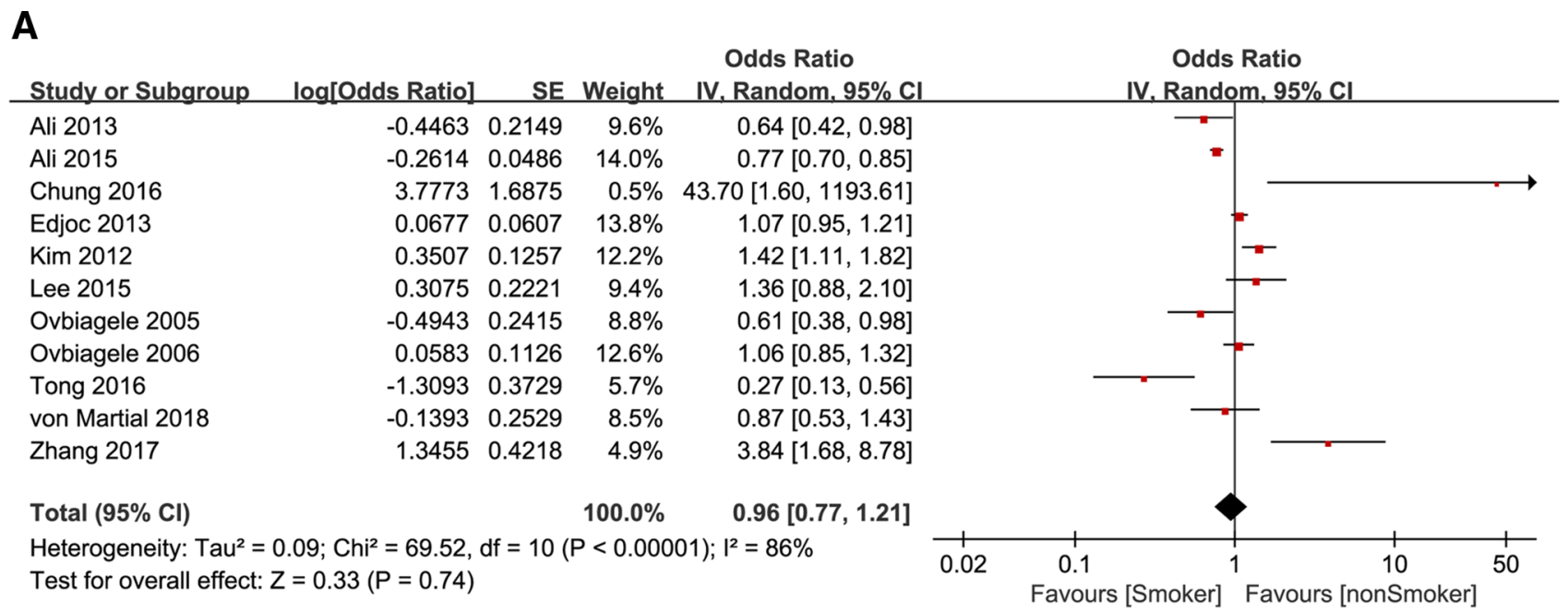

B

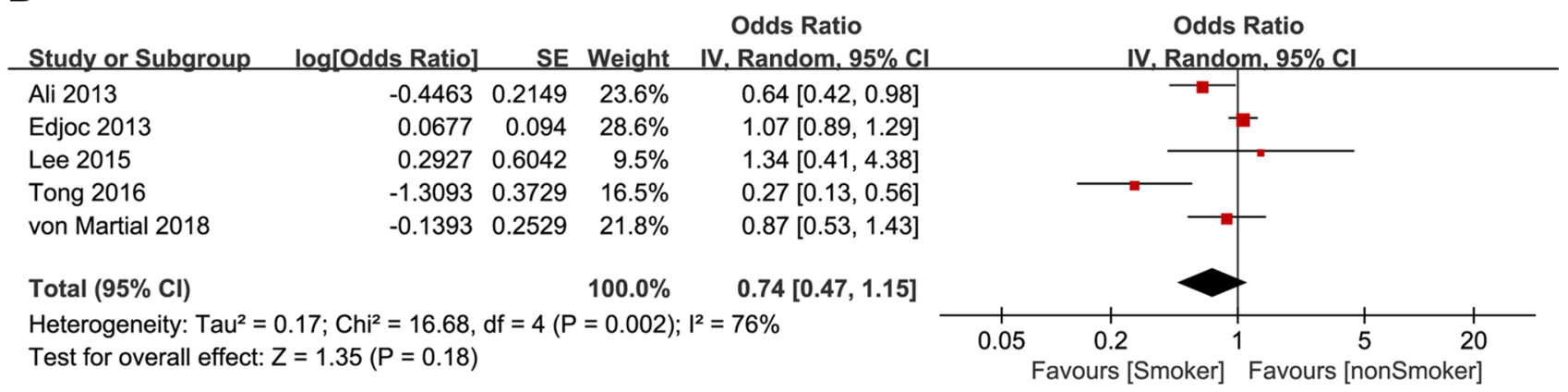

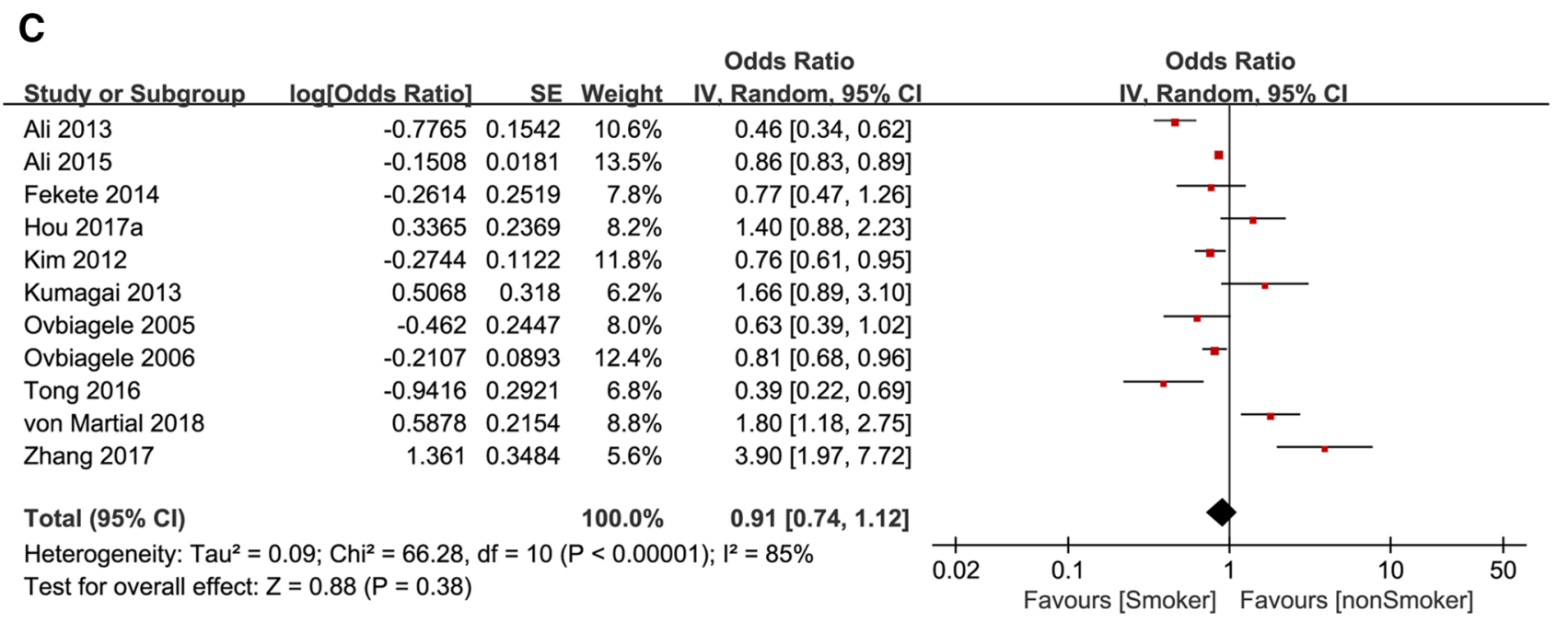

Fig. 2 a Forest plot of poor prognosis outcome odds ratio (full adjusted) among patients with ischemic stroke, smoking versus nonsmoking. b Forest plot of 90-day mortality odds ratio among patients

stroke. Compared with patients who never smoked, those who smoked during or before stroke had a greater risk of death or recurrent vascular events [5]. Nevertheless, the contradictory results, namely smoking paradox, were reported with ischemic stroke, smoking versus nonsmoking. $\mathbf{c}$ Forest plot of poor prognosis outcome odds ratio (unadjusted) among patients with ischemic stroke, smoking versus nonsmoking

in studies by many researchers who investigated the relationship between smoking and prognosis of stroke patients. Some of them reported that smoking in stroke patients may be independently associated with excellent clinical 


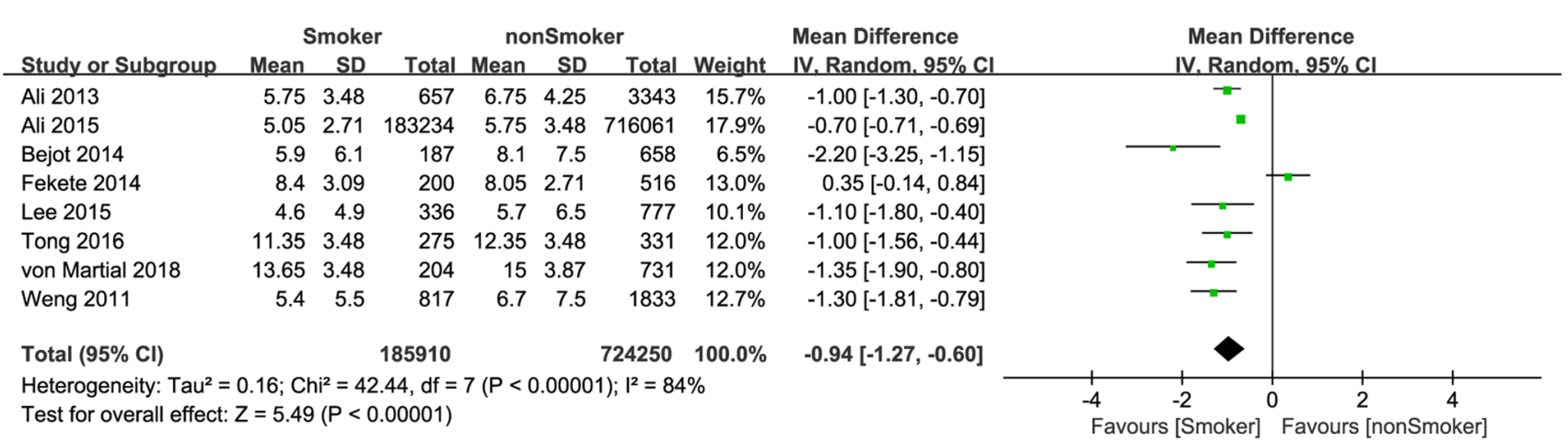

Fig. 3 Forest plot of mean difference of NIHSS at admission among patients with ischemic stroke, smoking versus nonsmoking

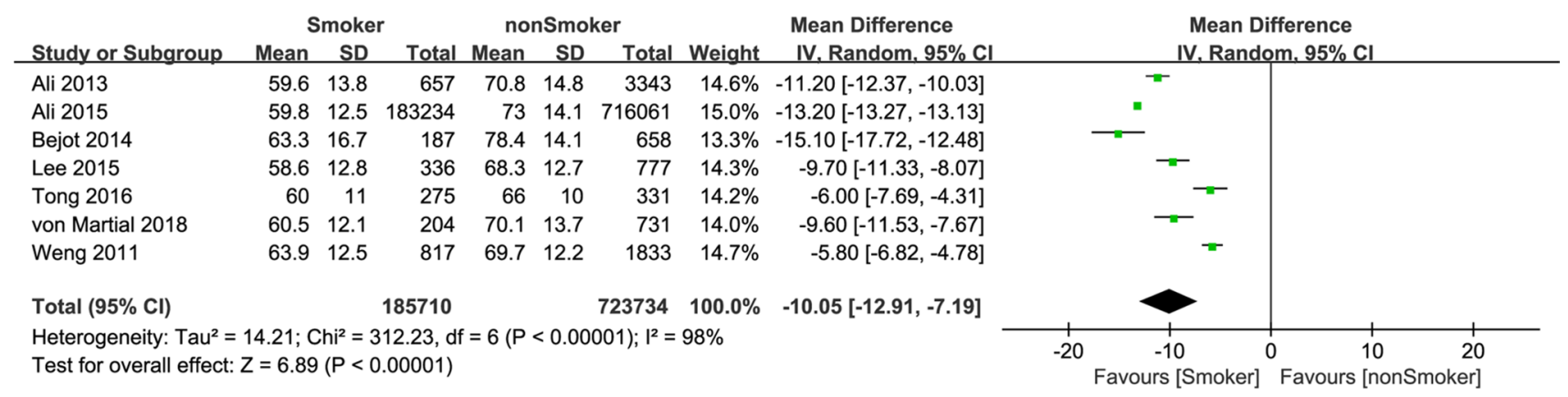

Fig. 4 Forest plot of mean difference of age at admission among patients with ischemic stroke, smoking versus nonsmoking

outcome after Endovascular Treatment (EVT) [24]. Tong et al. [23] recently reported that noncardioembolic stroke may be independently related to good outcome in smoking patients treated with Intravenous thrombolytic (IVT). The researchers believe that smokers may have better ischemic preconditioning due to elevated levels of carbon monoxide in the plasma and intermittent hypoxia [26]. Smokers may be supposed to have a better cerebral collateral supply as a further explanation for paradoxical association with clinical outcome, but collateral supply did not differ between groups in our study. These contradictory results prompted us to assess the prognostic impact of smoking and nonsmoking on patients with ischemic stroke to determine the correlation between smoking and IS prognosis. After adjusting factors such as age, sex, BMI and severity of stroke at admission, we found that smoking was not associated with the prognosis of IS. Even if covariates such as age, sex, BMI and severity of stroke were not adjusted, our results also exhibited that there was not correlation between smoking and the prognosis of IS. This suggested that the paradox "smoking is beneficial to the prognosis of ischemic stroke" is not valid. Smoking is not a protective factor for the prognosis of ischemic stroke. Those contradictory results might derive from the differences of study size.

This meta-analysis also indicated that smokers were 10 years younger than non-smokers at the onset of stroke, suggesting that smoking may cause the first onset of stroke to occur significantly ahead of time. A large number of studies have found that smoking produces more than 4000 gases, including carbon monoxide and nicotine [27]. Carbon monoxide can replace oxygen in hemoglobin, thus reducing the release of oxygen and directly reducing the oxygen supply to tissues and organs [28]. In addition, those toxic chemicals in cigarette smoke, such as nicotine, can lead to vascular endothelial dysfunction and inflammation, which ultimately leads to the development and acceleration of the atherosclerosis process. Smoking patients are assumed to have an increased hematocrit, platelet activation and aggregation, vasoconstriction and circulating fibrinogen [29-31]. Thus, smokers may have more thrombogenic than atherogenic vessel occlusion. The location of vessel occlusion may also play an important role. Smoking patients are more likely to have aortic occlusion, which directly affects the treatment effect and prognosis. In addition, smoking increases oxidative stress with the loss of the protective effect of NO tips the cellular balance towards a proatherogenic and prothrombotic milieu. All of these increase the risk of IS. Therefore, smoking is a risk factor for IS, making the patient suffering from IS 10 years earlier. This also explains why this meta-analysis reveals that the NIHSS score of smokers at admission is lower than that of non-smokers, and pooled $\mathrm{MD}=-0.89$, and most of the six included studies indicate that smokers 
A

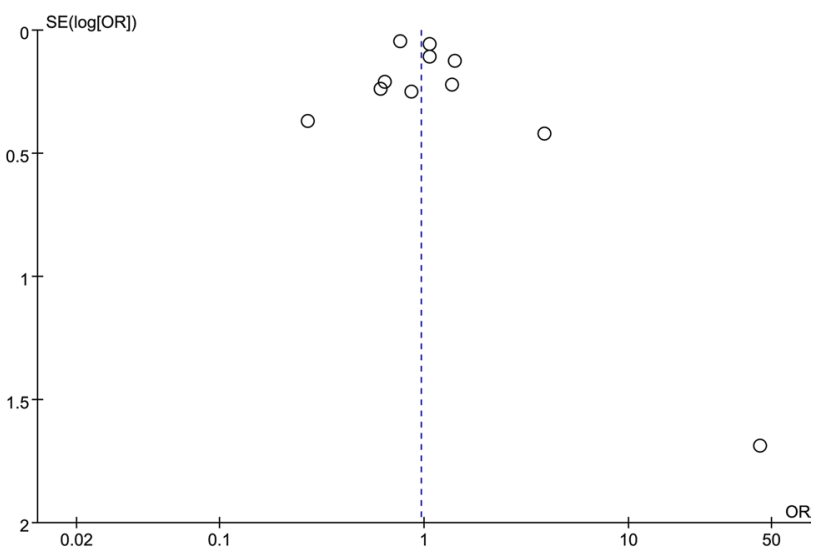

B

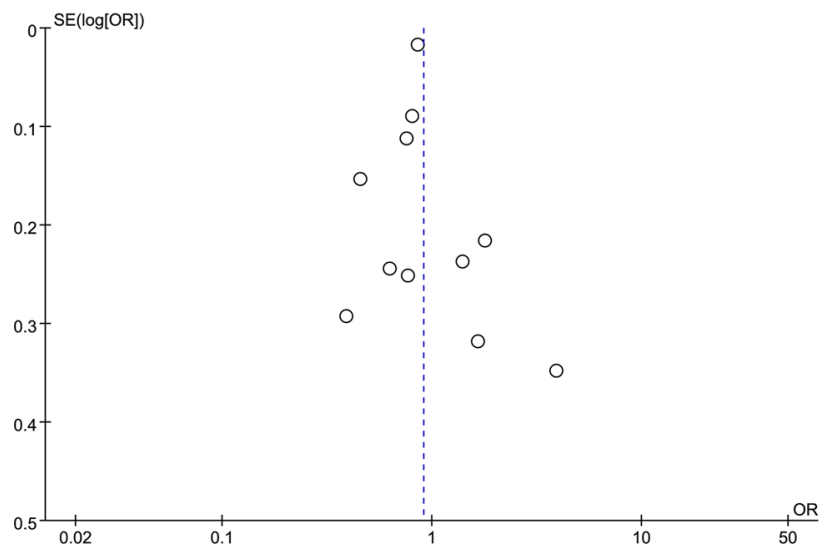

Fig. 5 a Funnel plot of poor prognosis outcome odds ratio (full adjusted) among patients with ischemic stroke, smoking versus nonsmoking. b Funnel plot of poor prognosis outcome odds ratio (unadjusted) among patients with ischemic stroke, smoking versus nonsmoking

are less ill than non-smokers. In five studies, NIHSS scores of smoking patients with ischemic stroke were lower than those of nonsmoking patients [10]. Only one study found that smoking patients with ischemic stroke had higher NIHSS scores than nonsmoking patients. Smoking patients with IS seem to be less ill. By the way, the NIHSS scores reported by these studies at admission are unadjusted for any of the influential variables. The NIHSS scores are related to many other factors, such as age. Significant differences in age between smoking patients and nonsmoking patients may be an important factor contributing to differences in NIHSS scores. The younger patients had lower NIHSS scores because their basic physical condition is relatively better. Smoking patients are 10 years younger and are less likely to have other traditional vascular risk factors compared with non-smokers. Although the study found that smokers' NIHSS scores were better than non-smokers, these age differences may partly explain the beneficial findings for smokers, as older age is often associated with worse physical conditions [24, 32]. Considering differences in baseline characteristics are essential for discussion of "smoking paradox" in stroke patients, the age is one of the important factors. According to a comprehensive consideration of factors, such as age, this meta-analysis determined that not only smoking was not related to the prognosis of IS, but also cause the first onset of IS to occur 10 years earlier. We believe that the smoking paradox is not true. We strongly recommend giving up smoking. The government should increase the nationwide education of tobacco harmness to health and increase the investment and intensity of tobacco control.

\section{Strengths and limitations of study}

The strength of this paper is that we synthesized 18 studies, comprising nearly 1 million samples, many of which are of large scale. Therefore, the evidence provided by us in this meta-analysis is sufficient to give a reliable estimate of the relative risks associated with smoking. Our analysis also has some limitations. First, between-studies heterogeneity can be increased due to definition of smoking that varies from study to study included. Second, between-studies heterogeneity can be increased due to paucity of data in subgroup analysis of stroke patients who quit smoking or continue to smoke after admission and during follow-up.

\section{Conclusions}

The "smoking paradox" is not true. Smoking has no protective effect on the poor prognosis of IS patients. Smoking IS patients are 10 years younger than nonsmoking IS patients at the time of first onset of stroke. Smoking is one of the most preventable causes of IS risk. This requires the government to strengthen tobacco control and raise people's awareness of reducing and quitting smoking.

Acknowledgements We would like to thank Beijing Zhiyun data technology co. LTD for providing data analysis service.

Author contributions All the authors have made substantial contributions to conception and design, acquisition of data, or analysis and interpretation of data. They have all participated in drafting of the paper or revising it critically for important intellectual content. All the authors have read and approved the final version of the manuscript.

Funding This research received no external funding.

\section{Compliance with ethical standards}

Conflicts of interest The authors declare that they have no conflict of interest. 
Ethics approval and consent to participate This article does not contain any studies with human participants performed by any of the authors. As a systematic review and meta-analysis, no ethical approval or consent to participate was required.

Open Access This article is distributed under the terms of the Creative Commons Attribution 4.0 International License (http://creativeco mmons.org/licenses/by/4.0/), which permits unrestricted use, distribution, and reproduction in any medium, provided you give appropriate credit to the original author(s) and the source, provide a link to the Creative Commons license, and indicate if changes were made.

\section{References}

1. Tram L, Veno SK, Dahm CC, Thomsen BH, Johansen MB, Overvad K, Schmidt EB (2018) Adipose tissue lipophilic index and risk of ischemic stroke-a danish case-cohort study. Nutrients. https ://doi.org/10.3390/nu10111570

2. Ning X, Sun J, Jiang R, Lu H, Bai L, Shi M, Tu J, Wu Y, Wang J, Zhang J (2017) Increased stroke burdens among the low-income young and middle aged in rural China. Stroke 48(1):77-83. https ://doi.org/10.1161/STROKEAHA.116.014897

3. Ng M, Freeman MK, Fleming TD, Robinson M, Dwyer-Lindgren L, Thomson B, Wollum A, Sanman E, Wulf S, Lopez AD et al (2014) Smoking prevalence and cigarette consumption in 187 countries, 1980-2012. JAMA 311(2):183-192. https://doi. org/10.1001/jama.2013.284692

4. O'Donnell MJ, Chin SL, Rangarajan S, Xavier D, Liu L, Zhang H, Rao-Melacini P, Zhang X, Pais P, Agapay S et al (2016) Global and regional effects of potentially modifiable risk factors associated with acute stroke in 32 countries (INTERSTROKE): a case-control study. The Lancet 388(10046):761-775. https://doi. org/10.1016/s0140-6736(16)30506-2

5. Kim J, Gall SL, Dewey HM, Macdonell RA, Sturm JW, Thrift AG (2012) Baseline smoking status and the long-term risk of death or nonfatal vascular event in people with stroke: a 10-year survival analysis. Stroke 43(12):3173-3178. https://doi.org/10.1161/strok eaha.112.668905

6. Kumagai N, Okuhara Y, Iiyama T, Fujimoto Y, Takekawa H, Origasa H, Kawanishi Y, Yamaguchi T (2013) Effects of smoking on outcomes after acute atherothrombotic stroke in Japanese men. J Neurol Sci 335(1-2):164-168. https://doi.org/10.1016/j. jns.2013.09.023

7. Ovbiagele B, Weir CJ, Saver JL, Muir KW, Lees KR (2006) Effect of smoking status on outcome after acute ischemic stroke. Cerebrovasc Dis 21(4):260-265. https://doi.org/10.1159/000091224

8. Aries MJH, Uyttenboogaart M, Koch MW, Langedijk M, Vroomen PC, Luijckx GJ, De Keyser J (2009) Does smoking influence outcome after intravenous thrombolysis for acute ischaemic stroke? Eur J Neurol 16(7):819-822. https://doi.org/10.111 1/j.1468-1331.2009.02596.x

9. Edjoc RK, Reid RD, Sharma M, Fang J (2013) The prognostic effect of cigarette smoking on stroke severity, disability, length of stay in hospital, and mortality in a cohort with cerebrovascular disease. J Stroke Cerebrovasc Dis 22(8):e446-454. https://doi. org/10.1016/j.jstrokecerebrovasdis.2013.05.001

10. Fekete K, Szatmari S, Szocs I, Szekeres C, Szasz J, Mihalka L, Smolanka V, Kardos L, Csiba L, Bereczki D (2014) Prestroke alcohol consumption and smoking are not associated with stroke severity, disability at discharge, and case fatality. J Stroke Cerebrovasc Dis 23(1):e31-37. https://doi.org/10.1016/j.jstrokecer ebrovasdis.2013.08.006
11. Moulin S, Padjen-Bogosavljevic V, Marichal A, Cordonnier C, Jovanovic DR, Gautier S, Henon H, Beslac-Bumbasirevic L, Bordet R, Leys D (2012) Influence of differences in case mix on the better outcome of smokers after intravenous thrombolysis for acute cerebral ischemia. Eur Neurol 67(3):178-183. https://doi. org/10.1159/000334847

12. Weng WC, Huang WY, Chien YY, Wu CL, Su FC, Hsu HJ, Lee TH, Peng TI (2011) The impact of smoking on the severity of acute ischemic stroke. J Neurol Sci 308(1-2):94-97. https://doi. org/10.1016/j.jns.2011.05.046

13. Moher D, Liberati A, Tetzlaff J, Altman D, Group P (2009) Preferred reporting items for systematic reviews and meta-analyses. The PRISMA statement. PLoS Med 6(7):e1000097. https://doi. org/10.1371/journal.pmed.1000097

14. Ali SF, Smith EE, Bhatt DL, Fonarow GC, Schwamm LH (2013) Paradoxical association of smoking with in-hospital mortality among patients admitted with acute ischemic stroke. J Am Heart Assoc 2(3):e000171. https://doi.org/10.1161/jaha.113.000171

15. Ali SF, Smith EE, Reeves MJ, Zhao X, Xian Y, Hernandez AF, Bhatt DL, Fonarow GC, Schwamm LH (2015) Smoking paradox in patients hospitalized with coronary artery disease or acute ischemic stroke: findings from get with the guidelines. Circ Cardiovasc Qual Outcomes 8(6 Suppl 3):S73-80. https:// doi.org/10.1161/circoutcomes.114.001244

16. Bejot Y, Jacquin A, Daubail B, Lainay C, Janoura S, AboaEboule C, Durier J, Giroud M (2014) Smoking status and severity of ischemic stroke. A population-based study. Eur Neurol 71(1-2):59-64. https://doi.org/10.1159/000355021

17. Chung CP, Chang FC, Huang HC, Tsai JY, Lin YY (2016) Impacts of cigarette smoking and basilar artery flow on 1-year recovery in 3-month survivors of intracranial vertebrobasilar artery dissection-related ischemic stroke. Acta Neurol Taiwan 25(3):75-82

18. Glymour MM, Defries TB, Kawachi I, Avendano M (2008) Spousal smoking and incidence of first stroke: the Health and Retirement Study. Am J Prev Med 35(3):245-248. https://doi. org/10.1016/j.amepre.2008.05.024

19. Hou L, Han W, Jiang J, Liu B, Wu Y, Zou X, Xue F, Chen Y, Zhang B, Pang H et al (2017) Passive smoking and stroke in men and women: a national population-based case-control study in China. Sci Rep 7:45542. https://doi.org/10.1038/srep45542

20. Hou LS, Du XD, Li JJ, Zhu P, Yan PJ, Zhan FY, Zhou MK, Zhu CR (2017) Long-term trends and predictors of smoking behaviors among men following first-ever ischemic stroke. J Huazhong Univ Sci Technol Med Sci 37(3):446-452. https://doi.org/10.1007/ s11596-017-1755-3

21. Lee JH, Lee JY, Ahn SH, Jang MU, Oh MS, Kim CH, Yu KH, Lee BC (2015) Smoking is not a good prognostic factor following first-ever acute ischemic stroke. J Stroke 17(2):177-191. https:// doi.org/10.5853/jos.2015.17.2.177

22. Ovbiagele B, Saver JL (2005) The smoking-thrombolysis paradox and acute ischemic stroke. Neurology 65(2):293-295. https://doi. org/10.1212/01.wnl.0000168163.72351.f3

23. Tong X, Wang C, Liao X, Pan Y, Yan H, Cao Y, Liu L, Zheng H, Zhao X, Wang C et al (2016) Smoking-thrombolysis relationship depends on ischemic stroke subtype. Stroke 47(7):1811-1816. https://doi.org/10.1161/strokeaha.116.013124

24. von Martial R, Gralla J, Mordasini P, El Koussy M, Bellwald S, Volbers B, Kurmann R, Jung S, Fischer U, Arnold M et al (2018) Impact of smoking on stroke outcome after endovascular treatment. PLoS ONE 13(5):e0194652. https://doi.org/10.1371/journ al.pone.0194652

25. Zhang Q, Wang Y, Song H, Hou C, Cao Q, Dong K, Huang X, Feng W, Ovbiagele B, Wang M et al (2017) Clopidogrel and ischemic stroke outcomes by smoking status: Smoker's paradox? J Neurol Sci 373:41-44. https://doi.org/10.1016/j.jns.2016.12.025 
26. Middleton ET, Morice AH (2000) Breath carbon monoxide as an indication of smoking habit. Chest 117(3):758-763. https://doi. org/10.1378/chest.117.3.758

27. Ambrose JA, Barua RS (2004) The pathophysiology of cigarette smoking and cardiovascular disease: an update. J Am Coll Cardiol 43(10):1731-1737. https://doi.org/10.1016/j.jacc.2003.12.047

28. Zevin S, Saunders S, Gourlay SG, Jacob P, Benowitz NL (2001) Cardiovascular effects of carbon monoxide and cigarette smoking. J Am Coll Cardiol 38(6):1633-1638. https://doi.org/10.1016/ s0735-1097(01)01616-3

29. Undas A, Topor-Madry R, Tracz W, Pasowicz M (2009) Effect of cigarette smoking on plasma fibrin clot permeability and susceptibility to lysis. Thromb Haemost 102(6):1289-1291. https://doi. org/10.1160/th09-03-0187
30. Purcell IF, Newall N, Farrer M (1999) Lower cardiac mortality in smokers following thrombolysis for acute myocardial infarction may be related to more effective fibrinolysis. QJM 92(6):327-333. https://doi.org/10.1093/qjmed/92.6.327

31. McGill HC Jr (1988) The cardiovascular pathology of smoking. Am Heart J 115(1 Pt 2):250-257. https://doi.org/10.1016/00028703(88)90645-X

32. Fukuoka T, Nakazato Y, Kawasaki H, Ikeda K, Furuya T, Miyake A, Mitsufuji T, Ito Y, Takahashi K, Araki N et al (2018) The clinical features of ischemic stroke patients for whom smoking was considered the sole risk factor for ischemic stroke. Intern Med 57(12):1703-1706. https://doi.org/10.2169/internalmedicin e.9655-17 